\title{
Candida infections in severe acute pancreatitis: we need to do more in order to distinguish invasive infection from simple colonization
}

\author{
Patrick M. Honore*, Aude Mugisha, Luc Kugener, Sebastien Redant, Rachid Attou, Andrea Gallerani and \\ David De Bels
}

We read with great interest the recent paper regarding anti-infective therapy for severe acute pancreatitis (SAP) by Montravers et al., who conclude regarding fungal infections that most of their cases received azoles in the context of both documented and empirical antifungal therapies [1]. We would like to make some comments. Candida is present in huge quantity in the colon. An increase over the years in Candida infection in nonneutropenic critically ill patients has been demonstrated to put them at increased risk of mortality and morbidity [2]. While there is a concern that this is the case in patients with SAP [3], this has not been universally demonstrated [4]. It is, however, likely that colonization plays an important instigating role in these invasive infections [4]. Patients with SAP are at a particular risk of invasive Candida infections. In a study by Hall and colleagues, both colonization with Candida spp. and a Candida colonization index score (CCIS) $>0.5$ were associated with subsequent infection [4]. The CCIS was calculated for each patient as follows: CCIS $=$ ratio of the number of non-blood distinct body sites colonized with Candida spp. to the total number of body sites cultured [4]. A CCIS $\geq 0.5$ predicts Candida infection; therefore, patients who had invasive Candida infections and a CCIS $\geq 0.5$ were defined as true positives [4]. In their commentary regarding the Hall paper, Montravers et al. themselves concluded that the mistakes of previous decades in the field of bacterial infection should not be repeated; a step-by-step approach is required [5]. Additional scientifically rigorous studies with accurate descriptions of cases similar to those in the article by Hall et al. [4] are required before prophylaxis or extensive therapeutic indications of antifungal agents in SAP can be proposed [5]. In conclusion, we believe that the cohort study of Montravers et al. should have discussed in more detail the importance of distinguishing between invasive Candida infections and colonization, noting, for instance, the utility of scoring systems such as the CCIS score in preventing unnecessary treatment for Candida colonization.

\section{Abbreviations \\ SAP: Severe acute pancreatitis; CCIS: Candida colonization index score \\ Acknowledgements \\ We would like to thank Dr. Melissa Jackson for the critical review of the manuscript.}

\section{Authors' contributions}

$\mathrm{PMH}, \mathrm{SR}$, and DDB designed the paper. All authors participated in drafting and reviewing the manuscript. All authors read and approved the final version of the manuscript.

\section{Funding}

None.

\section{Availability of data and materials Not applicable.}

Ethics approval and consent to participate Not applicable.

\footnotetext{
* Correspondence: Patrick.Honore@CHU-Brugmann.be

ICU Department, Centre Hospitalier Universitaire Brugmann-Brugmann

University Hospital, Place Van Gehuchtenplein, 4, 1020 Brussels, Belgium
} 


\section{Consent for publication}

Not applicable.

\section{Competing interests}

The authors declare to have no competing interests.

Received: 14 March 2020 Accepted: 6 April 2020

Published online: 16 April 2020

\section{References}

1. Montravers P, Kantor E, Constantin JM, Lefrant JY, Lescot T, Nesseler N, Paugam C, Jabaudon M, Dupont H. Epidemiology and prognosis of antiinfective therapy in the ICU setting during acute pancreatitis: a cohort study. Crit Care. 2019;23(1):393. https://doi.org/10.1186/s13054-019-2681-5.

2. Leon C, Ruiz-Santana S, Saavedra P, Almirante B, Nolla-Salas J, Alvarez-Lerma F, Garnacho-Montero J, Leon MA: A bedside scoring system ("Candida score") for early antifungal treatment in nonneutropenic critically ill patients with Candida colonization. Crit Care Med 2006,34:730-737.

3. Hoerauf A, Hammer S, Muller-Myhsok B, Rupprecht H. Intra-abdominal Candida infection during acute necrotizing pancreatitis has a high prevalence and is associated with increased mortality. Crit Care Med. 1998; 26:2010-5.

4. Hall AM, Poole LA, Renton B, Wozniak A, Fisher M, Neal T, Halloran CM, Cox T, Hampshire PA. Prediction of invasive candidal infection in critically ill patients with severe acute pancreatitis. Crit Care. 2013;17(2):R49. https://doi. org/10.1186/cc12569.

5. Montravers P, Boudinet S, Houissa H. Candida and severe acute pancreatitis: we won't be fooled again. Crit Care. 2013;17(3):137. https://doi.org/10.1186/ cc12613.

\section{Publisher's Note}

Springer Nature remains neutral with regard to jurisdictional claims in published maps and institutional affiliations. 